\title{
Effects of including forage herbs in grass-legume mixtures on persistence of intensively managed pastures sampled across three age categories and five regions
}

\author{
KN Tozer, GM Barker, CA Cameron, D Wilson \& N Loick
}

To cite this article: KN Tozer, GM Barker, CA Cameron, D Wilson \& N Loick (2016) Effects of including forage herbs in grass-legume mixtures on persistence of intensively managed pastures sampled across three age categories and five regions, New Zealand Journal of Agricultural Research, 59:3, 250-268, DOI: 10.1080/00288233.2016.1188831

To link to this article: https://doi.org/10.1080/00288233.2016.1188831

\section{曲 Published online: 03 Jul 2016.}

Submit your article to this journal $\pi$
III Article views: 487

Q View related articles 두

View Crossmark data ¿

Citing articles: 5 View citing articles 


\title{
Effects of including forage herbs in grass-legume mixtures on persistence of intensively managed pastures sampled across three age categories and five regions
}

\author{
KN Tozer ${ }^{a}$, GM Barker ${ }^{b}$, CA Cameron ${ }^{a}$, D Wilson ${ }^{a}$ and N Loick ${ }^{a, c}$ \\ ${ }^{a}$ AgResearch, Ruakura Research Centre, Hamilton, New Zealand; ${ }^{b}$ Landcare Research, Hamilton, New Zealand; \\ 'Rothamsted Research, Okehampton, Devon, UK
}

\begin{abstract}
To test the hypothesis that the inclusion of the forage herbs chicory (Cichorium intybus L.) or plantain (Plantago lanceolata L.) or both in a grass-legume pasture mix improves persistence of sown vegetation and reduces weed and invertebrate pest ingress, a study was undertaken in 31-44 intensively managed pastures in each of five regions in New Zealand (Northland, Waikato, Bay of Plenty, Taranaki and Canterbury). The regions were stratified according to farm type (dairy or sheep and beef), pasture type (sown with grasses, legumes and herbs or grasses and legumes) and pasture age (young: 1-2 years old; medium: $3-4$ years old; and old: 5+ years since sowing, $n=171)$. Sown species ground cover and emergence from the soil seed bank was greater, and unsown species ground cover and emergence lower, in sheep and beef pastures sown with herbs than without herbs ( $78 \%$ vs $68 \%$ ground cover, respectively, averaged over all pasture ages), but there was no difference between pasture types on dairy farms. Invertebrate predator and parasitoid abundance was $65 \%$ greater under pastures sown with herbs than without herbs. The number and \% dry matter contribution of sown species decreased, and that of unsown species increased, as pastures aged. Unsown species comprised $90 \%$ (sheep and beef) and $98 \%$ (dairy) of total seedling emergence. The inclusion of forage herbs increased persistence of sown species and reduced weed ingress, but only on sheep and beef farms.
\end{abstract}

\section{ARTICLE HISTORY}

Received 29 October 2014

Accepted 4 May 2016

\section{KEYWORDS}

Biodiversity; pasture performance; pasture persistence; pasture pests; weed invasion

\section{Introduction}

Poor persistence of permanent pastures is a major issue for the New Zealand pastoral industry. Lack of pasture persistence was ranked as the fourth most important issue affecting New Zealand sheep and beef farms, with farmers defining a persistent pasture as one that lasts for 7-10 years and remains free of weeds (Beef + Lamb New Zealand 2001). In a postal survey of 776 dairy farmers in the central North Island of New Zealand, poor persistence of renewed, predominantly perennial ryegrass (Lolium perenne L.)-based pastures was similarly ranked as one of the most important factors limiting farm economic performance (Kelly \& Smith 2011). In a recent study on the effect of pasture renewal on 
commercial dairy farms in the upper North Island, total annual dry matter (DM) production was greater in renewed pastures in the first, second and third years, but in the fourth and fifth years there was no yield benefit from renewal (Tozer et al. 2015). Most of those pastures were based on perennial ryegrass and white clover (Trifolium repens L.) and it was thought that drought and invertebrate pests contributed to the decline in DM production of the renewed pastures as they aged.

In response to these concerns regarding persistence, there has been an increased interest in alternative pasture species for sowing as monocultures or in combination with perennial ryegrass and white clover. Of particular interest has been the forage herbs chicory (Cichorium intybus L.) and plantain (Plantago lanceolata L.). However, most of the agronomic studies involving chicory and plantain are short term, and little is known about the longer-term contribution of these herbs under intensive management to persistence of pastures in which they are a sown component.

Short-term studies of 1-3 years have demonstrated increased DM production and content of sown vegetation as a result of adding herbs to a grass-legume mix under irrigation (Goh \& Bruce 2005; Høgh-Jensen et al. 2006; Nobilly et al. 2013) and under dryland conditions (Tharmaraj et al. 2014). For example, Tharmaraj et al. (2014) showed that over 4 years a $15 \%$ increase in total annual DM production can be achieved when red clover (T. pratense L.) and chicory were added to a dryland perennial ryegrass-white cloverbased sward grazed by dairy cattle.

Yield advantages occur because chicory and plantain are highly productive and drought tolerant, with extensive root systems (Stewart 1996; Li \& Kemp 2005). The deep-rootedness enables greater nutrient and moisture capture lower in the soil profile than is possible with more shallow-rooted species such as perennial ryegrass and white clover, demonstrated for example in studies of chicory and plantain (Stewart 1996; Sanderson \& Elwinger 2004; Li \& Kemp 2005; Høgh-Jensen et al. 2006; Moorhead \& Piggot 2009).

Inclusion of forage herbs in a grass-clover mix can change the seasonal feed supply and extend the growing season, with greater production occurring particularly in summer and autumn (Sanderson et al. 2004a; Pembleton et al. 2015). These changes in pasture growth can reduce weed ingress. One possible mechanism for this is that sowing a wider range of pasture species enables better resource utilisation, thus making it more difficult for weeds to invade. The extent to which this effect occurs will depend on how evenly the sown species are distributed throughout the pasture, rather than increasing the number of sown species per se (Sanderson et al. 2004a; Tracy et al. 2004). The impact of including forage herbs and other species on weed ingress was demonstrated in a 2 year study in USA dairy pastures sown with two, three, six or nine species. The three, six and nine species mixtures, which contained grasses, legumes and forage herbs, had fewer weeds than the two species mixture, inferring that the more complex mixture of grasses, legumes and forage herbs was more stable than the simpler grass-legume mixture (Sanderson et al. 2004b; Soder et al. 2006). However, little is known regarding weed ingress over time in intensively managed pastures containing forage herbs.

Adding forage herbs to a mix comprising grasses and legumes is likely to affect invertebrate abundance. The inclusion of herbs will alter the sward architecture, potential invertebrate habitat and food sources (Curry 1994). No published studies could be found on the impacts of adding forage herbs on invertebrate abundance in intensively managed pastures on sheep and beef or dairy farms, despite the increasing use of forage herbs in the 
New Zealand pastoral sector. Increasing our understanding of this across enterprise types is important as invertebrate pests can have a large impact on pasture performance (Zydenbos et al. 2011).

Given the possible effects of forage herbs on pasture persistence, we designed a study to test the hypothesis that inclusion of forage herbs in a grass-legume mix improved the persistence of sown species, and reduced weed and pest ingress of intensively managed pastures. The design included two key farm types (dairy, and sheep and beef), three pasture age categories and five New Zealand regions, four of which were in the North Island and one in the South Island. These two key farm types were chosen because of the differences between sheep and cattle grazing behaviour and potential impacts on pasture persistence. The three age categories enabled changes over time to be assessed, and conducting the survey in five regions enabled treatment effects to be determined under a range of climatic conditions.

\section{Methods}

\section{Sampling design}

Sampling was carried out across five regions of New Zealand to examine the botanical and invertebrate community composition of pastures of two categories-those sown with grasses, legumes and herbs (GLH), and those sown with grasses and legumes (GL) - along a gradient of years since pasture sowing (age). With respect to herbs, we considered only chicory and plantain, as these are the predominant forage herbs available for use throughout the New Zealand pastoral industry (Stewart 1996; Lee et al. 2012). Pastures were assigned to three age classes: (1) 'young': sown in the past 1-2 years; (2) 'medium': 3-4 years; and (3) 'old': 5+ years. This age gradient enabled assessment of whether sown components persisted, and the longevity of herb addition effects.

The five regions and farm types sampled were: Northland (11 sheep and beef farms), Waikato (16 dairy), Bay of Plenty (10 dairy) and Taranaki (10 dairy); and one South Island region: Canterbury (nine sheep and beef, and three deer farms which were included in the sheep and beef farm analyses). Between 31 and 44 pastures were sampled in each region, with between one and five pastures per farm (average three pastures per farm)

Table 1. Number of pastures sampled for each pasture type $\times$ pasture age category, in each of five regions.

\begin{tabular}{|c|c|c|c|c|c|c|}
\hline \multirow[b]{2}{*}{ Pasture type } & \multirow[b]{2}{*}{ Age (years since sowing) } & \multicolumn{3}{|c|}{ Dairy farms } & \multicolumn{2}{|c|}{ Sheep and beef farms } \\
\hline & & Waikato & Bay of Plenty & Taranaki & Northland & Canterbury \\
\hline \multirow[t]{4}{*}{ GLH } & Young & 9 & 6 & 5 & 6 & 5 \\
\hline & Medium & 5 & 5 & 4 & 7 & 5 \\
\hline & Old & 7 & 5 & 6 & 5 & 6 \\
\hline & Total & 21 & 16 & 15 & 18 & 16 \\
\hline \multirow[t]{4}{*}{ GL } & Young & 11 & 5 & 5 & 4 & 7 \\
\hline & Medium & 6 & 5 & 6 & 5 & 4 \\
\hline & Old & 6 & 5 & 6 & 5 & 5 \\
\hline & Total & 23 & 15 & 17 & 14 & 16 \\
\hline
\end{tabular}

A total of 171 dairy, and sheep and beef pastures were sampled on a total of 59 farms.

$\mathrm{GLH}$, pastures sown with a mixture of grasses, legumes and herbs; GL, pastures sown with a mixture of grasses and legumes; Young, sown in the past 1-2 years; Medium, 3-4 years; Old, 5+ years. 
and approximately five pastures were included for each age and pasture type (GLH vs GL) category within each region. The total sample size was 171 pastures (Table 1).

\section{Pasture selection}

Pastures were selected from a database established from interviews with farmers, with spatial autocorrelation minimised by ensuring no more than one example of pasture type by age category was sampled within a single farm.

Industry networks were used to identify farms on which pastures had been renewed and farms were randomly selected from the industry list. Within each farm, pastures were randomly selected provided that they met criteria. Pastures were only selected if: (1) farmers possessed knowledge of the year in which the pasture was sown, species and cultivars sown, sowing rates, presence of seed coating, endophyte status and pasture renewal method; (2) they were not irrigated (other than effluent spreading on several dairy pastures); and (3) no pasture species had been added to the pasture through drilling (undersowing) or broadcasting (oversowing) seed since renewal. Pasture sizes varied considerably, although most dairy pastures were approximately 1.5 hectares and sheep and beef pastures were a minimum of 2 hectares. Dairy pastures were typically rotationally grazed, and beef and sheep pastures also rotationally grazed except for continuous stocking during lambing in spring.

\section{Pasture renewal variables}

Information was obtained from farmers for each pasture sampled regarding: (1) the use of cropping prior to sowing the permanent perennial pasture; (2) preparation of the seedbed (cultivation vs no tillage); (3) sowing technique (drilling vs broadcasting); (4) use of Epichlö̈ endophytes; and (5) presence or absence of an insecticide seed coating.

\section{Climate}

Climate data for each pasture were obtained from the New Zealand National Climate Database, using the nearest meteorological station as a proxy. These data were interpolated for each site, according to Tait et al. (2006). For each pasture, annual climate data means were averaged over the lifetime of the pasture (from the year of sowing to the year in which the sampling was undertaken). Variables assessed include maximum and minimum air temperatures, soil temperature at a depth of $10 \mathrm{~cm}$, rainfall, evaporation and solar radiation. Rainfall data were used as a covariate in the analyses.

\section{Assessments}

Assessments were undertaken during spring (September-November) 2009 for Northland, Waikato, Taranaki; autumn 2010 for Canterbury; and spring 2010 for Bay of Plenty. Botanical, soil seed bank, invertebrate and endophyte sampling were undertaken in the same areas within the paddock. Pastures were sampled 2 or more weeks after their previous grazing except for a small number of pastures that were continuously stocked. 


\section{Dry matter contribution}

Assessing the DM contribution of sown and unsown species gives an indication of the agronomic performance of the pasture. The proportion of sown and unsown grasses, legumes and herbs in the pasture at the time of sampling was assessed in $20,0.1 \mathrm{~m}^{2}$ quadrats in each paddock, using the BOTANAL method (Tothill et al. 1992). Briefly, this method involves visually ranking the three most dominant vegetation classes present in each quadrat with respect to their contribution to standing DM. Standard multipliers are then used to estimate the contribution of these vegetation classes to total pasture DM (Jones \& Hargreaves 1979; Tothill et al. 1992; Nijland 2000). This method may lead to an underestimate of the contribution of minor species (Lavorel et al. 2008), which are better detected in ground cover assessments.

\section{Ground cover}

Ground cover is useful for assessing horizontal space occupation which is related to sward characteristics such as resistance to invasion (Lavorel et al. 2008). Using random sampling, the percentage of ground cover and bare ground in a pasture was visually estimated in four $2 \times 2 \mathrm{~m}$ quadrats, by the same operator on all occasions. Within each quadrat, sown and unsown grasses, legumes and herbs were identified.

\section{Soil seed bank}

The soil seed bank was assessed to determine which species were present, as this gives an indication of their potential contribution to seedling recruitment and weed ingress. Within each region, three of the pastures in each 'pasture type $\times$ pasture age' category were randomly chosen for an assessment of the composition of the soil seed bank-giving 18 pastures in each region. In each pasture, 20 soil cores $(2.5 \mathrm{~cm}$ diameter and $7 \mathrm{~cm}$ deep) were collected at $1 \mathrm{~m}$ intervals along a transect. Sampling depth was based on prior knowledge that seed numbers in New Zealand pastures are high in the upper $5 \mathrm{~cm}$ of soil and rapidly decline in deeper layers (e.g. Bell 1995). Following the methodology of Rahman et al. (1995), a $500 \mathrm{~g}$ subsample was obtained by sieving to remove vegetative material and coarse aggregates. Propagation trays $(550 \times 340 \mathrm{~mm} \times 110 \mathrm{~mm}$ deep $)$ were filled to 50 $\mathrm{mm}$ depth with potting mix to provide a moisture reservoir. A layer of weed mat was placed over the potting mix and the sieved soil sample placed on top of the weed mat in a $20 \mathrm{~mm}$ layer. Trays were maintained at $18-23{ }^{\circ} \mathrm{C}$ in a glasshouse and subirrigated as required to keep the soil moistened. Emerged seedlings were identified and then removed, until seedling emergence ceased after 7 weeks. Most seedling emergence from the seed bank occurs within the first week using this method (Rahman et al. 1995).

\section{Invertebrate community assessments}

Invertebrates were sampled in the same pastures in which soil seed bank assessments were done. The composition of above ground (epigeal) invertebrate communities was estimated by collection of meso- and macro-fauna along three randomly selected $30 \mathrm{~m}$ transects per site using a suction apparatus (modified blower vacuum) with a $10 \mathrm{~cm}$ diameter collection sleeve. Collected invertebrates were stored in $70 \%$ ethanol until they were sorted in the laboratory and identified to species. The soil macro-fauna was sampled from 10 spade squares $(20 \times 20 \mathrm{~cm})$ taken to $20 \mathrm{~cm}$ depth at approximately $5 \mathrm{~m}$ intervals along a $50 \mathrm{~m}$ transect per site. These invertebrates were generally identified and counted in the field, 
with some specimens taken to the laboratory for identification under the stereomicroscope.

\section{Soil nutrients}

In each pasture, 30 cores $(25 \mathrm{~mm}$ diameter $\times 75 \mathrm{~mm}$ deep) were collected along the same transect as used for the invertebrate sampling and sent to a commercial laboratory for analyses. Results are reported using Ministry of Agriculture and Forestry (MAF) Quick Test (QT) units, as described by Cornforth (1980) and Cornforth and Sinclair (1984).

\section{Endophyte}

Endophyte infection levels were tested to give an indication of vulnerability of the host perennial grass species to predation by invertebrate foliar pests. Endophyte infection levels were tested using the tissue print immunoblot assay of Hahn et al. (2003) in the pastures in which soil seed bank assessments were done. A vegetative tiller of perennial ryegrass (or tall fescue in the few tall fescue-based pastures) was cut at ground level from 100 different clumps and sap from each tiller was squeezed on to nitrocellulose blotting paper. Subsequent colour development enabled presence/absence of endophyte to be determined and the frequency of endophyte infection estimated for each pasture.

\section{Statistical analyses}

Ground cover, \% DM contribution, seedling emergence from the soil seed bank, invertebrate abundance, endophyte infection in sown grasses, and soil nutrient data were analysed using residual maximum likelihood (REML) (Patterson \& Thompson 1971) in GenStat, 13th edition (GenStat 2010). These analyses fitted farm type (dairy vs beef and sheep), pasture type and pasture age and all interactions as fixed effects, and farm as a random effect. The three deer farms were included in the beef and sheep farm analyses. The residual average annual rainfall, after fitting region, was included in the analyses as a covariate. This controlled for variation in rainfall between farms within a region, while preserving rainfall differences between regions. A general linear mixed model (GLMM) was used to analyse pasture renewal variables, fitting main effects only. Above ground vegetation and seedling emergence from the seed bank were categorised as sown or unsown grasses, legumes and herbs. Epigeal invertebrates were categorised as herbivores, detritivores or predators and parasitoids. Botanical composition and seed bank data were angular transformed; no other data required transformation. Canterbury invertebrate data (which were collected in autumn [April] 2010) were omitted from the analyses as there was a significant effect of time of sampling on the results.

Due to the large number of statistical comparisons, all highly significant main effects and interactions are reported in the text $(P \leq 0.01)$ but less significant interactions $(P<$ $0.05)$ are only reported if they had a plausible biological explanation. Untransformed means and standard errors are presented but $P$ values pertain to analyses performed on transformed values. 


\section{Results}

\section{Pasture renewal variables}

There was much variability between farms and regions in the pasture renewal process. A cropping phase prior to sowing the perennial pasture mix occurred for $75 \%$ of all pastures sampled, with the remainder going straight from the old pasture into a new pasture without a cropping phase. An average of $67 \%$ of all pastures were cultivated prior to sowing the perennial pasture mix. The seed mix was sown by drilling the seed in an average of $67 \%$ of all pastures, with the remainder sown by broadcasting. An average of $77 \%$ of all pastures were sown with ryegrass or tall fescue seed infected by Epichloë endophyte, while the use of grass or legume seed coated with an insecticide, fungicide or both was much lower, averaging $38 \%$ of pastures (Figure 1).

\section{Climate}

The five regions varied in climate (Table 2). Northland (beef and sheep), Waikato and Bay of Plenty regions (both dairy) are characterised by relatively mild winters (especially Northland) and warm summers. Cool season $\left(C_{3}\right)$ species predominated but $C_{4}$ summer-active grasses occurred as unsown weed species. Of the North Island regions, Taranaki (dairy) was the coolest and wettest. It had the least evaporation and consequently the highest annual rainfall:potential evapotranspiration (PET) ratio. Canterbury (beef and sheep), had the lowest rainfall and lowest annual rainfall:PET ratio, and was subject to hot dry summers and cold winters.

When rainfall within region was used as a covariate, there was no significant difference between sheep and beef, and dairy farms in the annual average maximum and minimum

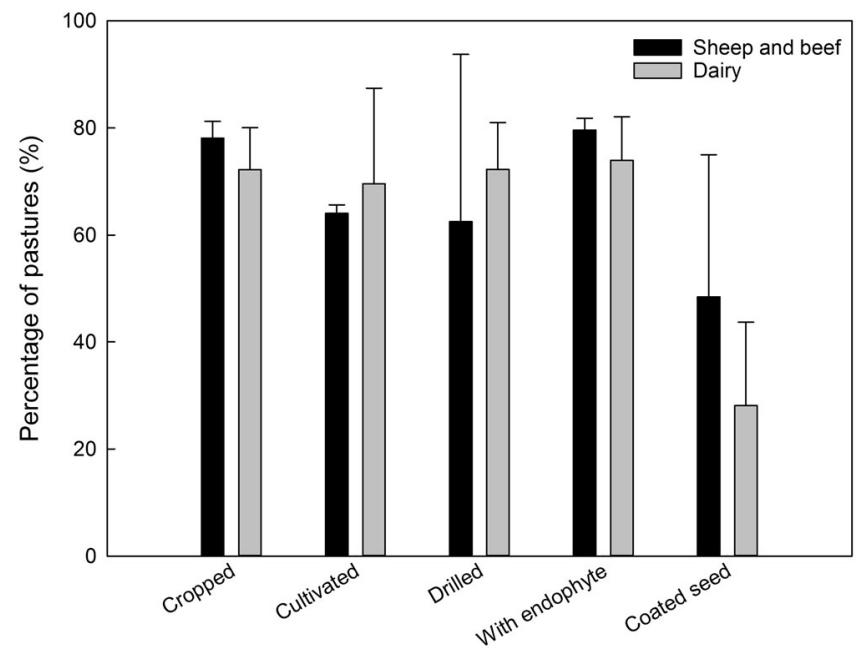

Figure 1. Percentage of sampled pastures in either sheep and beef, or dairy enterprises which utilised: (1) a cropping phase prior to sowing the new pasture; (2) cultivation of the seedbed prior to sowing; (3) a drilling method to sow pasture seed (as opposed to broadcasting seed); (4) grass seed infected with an endophyte; and (5) grass, legume or grass and legume seed coated with an insecticide (vs uncoated seed). Sheep and beef ( $\mathbf{\square}$ ) or dairy (घ). Data are based on sampling 171 pastures, on 59 farms, in five regions of New Zealand. 
Table 2. Average air and soil temperatures, rainfall, potential evapotranspiration (PET) and solar radiation data obtained from the New Zealand National Climate Database.

\begin{tabular}{|c|c|c|c|c|c|c|c|}
\hline \multirow[b]{2}{*}{ Climatic variable } & \multicolumn{3}{|c|}{ Dairy } & \multicolumn{2}{|c|}{ Sheep and beef } & \multirow[b]{2}{*}{ SED } & \multirow[b]{2}{*}{$F$ prob } \\
\hline & Waikato & Bay of Plenty & Taranaki & Northland & Canterbury & & \\
\hline Maximum air temperature $\left({ }^{\circ} \mathrm{C}\right)$ & 19.2 & 19.0 & 16.7 & 19.0 & 17.3 & 0.19 & $<0.001$ \\
\hline Minimum air temperature $\left({ }^{\circ} \mathrm{C}\right)$ & 9.1 & 8.8 & 8.9 & 11.4 & 6.5 & 0.26 & $<0.001$ \\
\hline Average soil temperature $\left({ }^{\circ} \mathrm{C}\right)$ & 14.3 & 13.6 & 12.8 & 15.0 & 10.8 & 0.15 & $<0.001$ \\
\hline Annual rainfall (mm) & 1280 & 1560 & 1810 & 1460 & 800 & 185 & $<0.001$ \\
\hline Annual PET (mm) & 895 & 997 & 878 & 958 & 948 & 18.3 & $<0.001$ \\
\hline Annual rainfall:PET ratio & 1.4 & 1.6 & 2.2 & 1.5 & 0.8 & 0.26 & $<0.001$ \\
\hline Solar radiation $\left(\mathrm{MJ} \mathrm{m}^{-2}\right)$ & 5300 & 5520 & 5290 & 4840 & 4930 & 79 & $<0.001$ \\
\hline
\end{tabular}

Data are interpolated from the nearest weather stations for each farm. For each variable, annual means were obtained for each pasture, and averaged over the period from the year of sowing to the year in which the pasture was sampled. The standard error of difference (SED) and $F$ probability ( $F$ prob) are given for comparison between all five regions.

air and soil temperatures, potential evapotranspiration and rainfall:PET ratio (when averaged over the age of each pasture, from the year of sowing until the year in which the pasture was sampled). However, solar radiation levels were higher on the dairy pastures in Waikato, Bay of Plenty and Taranaki than the sheep and beef pastures in Northland and Canterbury (5329 vs $4960 \mathrm{MJ} \mathrm{m}^{-2}$ per year, $P=0.017$ ).

\section{Botanical assessments}

\section{Sown species present}

All pastures were based entirely on $\mathrm{C}_{3}$ species, but the species sown varied with region (Table 3). Sown grasses included: perennial ryegrass, tall fescue (Schedonorus arundinaceus [Schreb.] Dumort.), cocksfoot (Dactylis glomerata L.), prairie grass (Bromus willdenowii Kunth), grazing bromes (Bromus spp.), timothy (Phleum pratense L.) and phalaris (Phalaris aquatica L.). Sown perennial ryegrass and tall fescue were nearly always infected with: Max P endophyte (Epichloë coenophiala [Morgan-Jones \& W. Gams] C.W. Bacon \& Schardl) for tall fescue, and wildtype, AR1, AR37, NEA2 or Endo5 endophyte (Epichlö̈ festucae var. lolii [Latch, M.J. Chr. \& Samuels] C.W. Bacon \& Schardl.) for perennial ryegrass (Leuchtmann et al. 2014). Sown legumes included white clover, which was sown in all pastures, red clover, subterranean clover (T. subterraneum L.), lucerne (Medicago sativa L.)

Table 3. Average percentage ground cover of the nine most prevalent species based on a sample of 171 dairy, sheep and beef pastures, on 59 farms, in five regions of New Zealand.

\begin{tabular}{|c|c|c|c|c|c|}
\hline \multirow[b]{2}{*}{ Species } & \multicolumn{3}{|c|}{ Dairy } & \multicolumn{2}{|c|}{ Sheep and beef } \\
\hline & Waikato & Bay of Plenty & Taranaki & Northland & Canterbury \\
\hline Lolium spp. & $42(4.4)$ & $44(8.0)$ & $58(8.5)$ & $44(8.0)$ & $37(9.0)$ \\
\hline Tall fescue & $1(0.8)$ & $1(1.4)$ & $2(2.0)$ & $1(1.4)$ & \\
\hline Cocksfoot & & & & & $2(1.8)$ \\
\hline White clover & $21(3.7)$ & $11(1.9)$ & $11(2.7)$ & $11(1.9)$ & $9(3.2)$ \\
\hline Subterranean clover & & & & & $3(1.9)$ \\
\hline Red clover & & & & & $2(2.7)$ \\
\hline Annual poa & $5(1.8)$ & $6(1.8)$ & & $5(1.8)$ & \\
\hline Plantain & & $4(2.1)$ & $2(1.2)$ & $3(2.1)$ & \\
\hline Creeping buttercup $^{a}$ & $1(0.7)$ & & $2(1.6)$ & & \\
\hline
\end{tabular}

Data are averaged over pasture type and pasture age categories. Species were only included if they were present in at least 10 pastures in each region. White clover was sown in all pastures. Presented are back-transformed means of the angular transformed data. Back-transformed standard errors are in parenthesis.

${ }^{\mathrm{a}}$ Ranunculus repens $L$. 
and lotus (Lotus spp.). Either chicory, plantain or both were always sown in the pastures sown with herbs.

\section{Number of species}

The number of species sown (4.3 vs 2.7), sown species present at the time of sampling (3.6 vs 2.3 ), sown species lost from the pastures ( 0.8 vs 0.3$)$ and total number of species present (11 vs 9.3) were all higher in pastures sown with a GLH mix than a GL mix $(P<0.01)$. The number of unsown species present, averaging 7, was similar across pasture type (Table 4 ). As pastures aged, the total number of species present increased, which reflected the increase in the number of unsown species from 5.8 in young pastures to 7.8 in old $(P<0.001)$. The number of sown species not persisting from sowing to the date of our sampling (henceforth referred to as 'missing') also increased from 0.2 in young pastures to 0.8 in old $(P<0.001$,

Table 4. Numbers of species (sown and unsown), botanical composition (\% ground cover and \% of total dry matter of sown and unsown grasses, legumes and herbs) and emergence of seedlings from the seed bank.

\begin{tabular}{|c|c|c|c|c|c|c|c|c|c|}
\hline \multirow[b]{2}{*}{ Variable } & \multicolumn{4}{|c|}{ Pasture type } & \multicolumn{5}{|c|}{ Pasture age } \\
\hline & GLH & GL & SED & $F$ prob & Young & Medium & Old & SED & $F$ prob \\
\hline \multicolumn{10}{|l|}{ Numbers of species } \\
\hline Species sown & 4.3 & 2.7 & 0.14 & $<0.001$ & 3.2 & 3.7 & 3.6 & 0.15 & 0.002 \\
\hline Sown spp. present & 3.6 & 2.3 & 0.11 & $<0.001$ & 3.0 & 3.0 & 2.9 & 0.12 & ns \\
\hline Sown spp. missing & 0.8 & 0.3 & 0.12 & 0.002 & 0.2 & 0.6 & 0.8 & 0.13 & $<0.001$ \\
\hline Unsown spp. present & 7.0 & 7.0 & 0.43 & ns & 5.8 & 7.5 & 7.8 & 0.51 & $<0.001$ \\
\hline Total spp. present & 11.0 & 9.3 & 0.44 & 0.002 & 8.8 & 10.7 & 11.1 & 0.52 & $<0.001$ \\
\hline \multicolumn{10}{|c|}{ Botanical composition (\% of total dry matter) } \\
\hline Sown grasses & 54 & 65 & 3.5 & 0.019 & 65 & 63 & 52 & 4.0 & 0.002 \\
\hline Sown legumes & 14 & 16 & 2.1 & ns & 19 & 13 & 14 & 2.4 & 0.036 \\
\hline Sown herbs & 10 & $-{ }^{\mathrm{a}}$ & - & - & 10 & 14 & 5 & 2.8 & 0.013 \\
\hline Total sown & 78 & 80 & 3.1 & ns & 88 & 81 & 69 & 3.4 & $<0.001$ \\
\hline Unsown grasses & 12 & 11 & 2.7 & ns & 5 & 12 & 17 & 2.9 & $<0.001$ \\
\hline Unsown legumes & 1 & 2 & 0.8 & ns & 2 & 0 & 2 & 1.0 & ns \\
\hline Unsown herbs & 9 & 7 & 1.4 & ns & 4 & 7 & 13 & 1.6 & $<0.001$ \\
\hline Total unsown & 21 & 20 & 3.1 & ns & 11 & 19 & 31 & 3.4 & $<0.001$ \\
\hline \multicolumn{10}{|c|}{ Botanical composition (\% ground cover) } \\
\hline Sown grasses & 50 & 57 & 3.5 & ns & 57 & 54 & 48 & 3.9 & 0.057 \\
\hline Sown legumes & 19 & 17 & 2.5 & ns & 21 & 16 & 16 & 2.8 & ns \\
\hline Sown herbs & 6 & $-^{a}$ & - & - & 7 & 9 & 3 & 1.6 & 0.003 \\
\hline Total sown & 74 & 73 & 3.1 & ns & 81 & 74 & 66 & 3.4 & $<0.001$ \\
\hline Unsown grasses & 12 & 12 & 2.7 & ns & 5 & 14 & 17 & 3.0 & $<0.001$ \\
\hline Unsown legumes & 2 & 3 & 1.2 & ns & 3 & 1 & 4 & 1.4 & ns \\
\hline Unsown herbs & 9 & 6 & 1.2 & ns & 5 & 7 & 11 & 1.4 & $<0.001$ \\
\hline Total unsown & 23 & 22 & 3.2 & ns & 13 & 22 & 31 & 3.5 & $<0.001$ \\
\hline Bare ground & 3 & 5 & 1.1 & ns & 6 & 4 & 3 & 1.3 & 0.009 \\
\hline \multicolumn{10}{|c|}{ Seed bank (emerged seedlings $\mathrm{m}^{-2}$ ) } \\
\hline Total sown & 7 & 3 & 1.9 & 0.049 & 5 & 4 & 5 & 2.4 & ns \\
\hline Total unsown & 106 & 109 & 19.4 & ns & 121 & 99 & 103 & 24.5 & ns \\
\hline \multicolumn{10}{|c|}{ Seed bank (percentage of total emergence) } \\
\hline Total sown & 9 & 3 & 2.3 & 0.019 & 6 & 8 & 5 & 2.9 & ns \\
\hline Unsown grasses & 40 & 34 & 5.3 & ns & 38 & 41 & 32 & 6.5 & ns \\
\hline Unsown herbs & 50 & 61 & 5.5 & 0.046 & 54 & 51 & 61 & 6.8 & ns \\
\hline Total unsown & 91 & 97 & 2.3 & 0.019 & 94 & 92 & 95 & 2.9 & ns \\
\hline
\end{tabular}

Emergence data are expressed as numbers of emerged seedlings and percentage of total emergence for the sown and unsown grasses, legumes and herbs, for 171 dairy, and sheep and beef pastures, varying in pasture type (GLH, grasses, legumes and herbs; GL, grasses and legumes) and pasture age (Young, sown in the past 1-2 years; Medium, 3-4 years; Old, 5+ years). SED, standard error of difference; ns, not significant $(P>0.05)$.

${ }^{a}$ Statistical analyses undertaken on GLH treatments only for sown herbs. 
Table 4). The number of sown, missing, unsown and total species was similar in dairy and in sheep and beef pastures $(P>0.05$, data not shown).

\section{Botanical composition: percentage contribution to total dry matter}

The proportion of total pasture DM provided by sown grasses was lower in pastures sown with a GLH mix than a GL mix (54\% vs $65 \%, P=0.019$, Table 4$)$ and declined with pasture age from $65 \%$ in young pastures to $52 \%$ in old $(P=0.002)$. Sown legume $\% \mathrm{DM}$ contribution declined with pasture age from $19 \%$ in young pastures to an average of $14 \%$ in medium and old $(P=0.036)$. Sown herbs and total sown species DM both declined with pasture age; sown herbs declined from an average of $12 \%$ in young and medium pastures to only $5 \%$ of total DM in old pastures $(P=0.013)$ and total sown species declined from $88 \%$ of total DM in young pastures to $69 \%$ in old $(P<0.001)$.

The contribution of unsown grasses, unsown herbs and total unsown species to pasture DM increased three-fold with pasture age $(P<0.001)$. In old pastures, the contribution of total unsown species reached $31 \%$ of total DM. Unsown legumes remained a small component of the sward (averaging $2 \%$ of total DM) and were similar across farm type, pasture type and pasture age $(P>0.05)$.

\section{Botanical composition: percentage of total ground cover}

Percentage ground cover of sown grasses, averaging 53\%, and sown legumes, averaging $18 \%$, were similar across farm type, pasture type and pasture age (Table 4). Sown herbs comprised $6 \%$ of total ground cover in pastures sown with a GLH mix. Cover of sown herbs declined with pasture age, averaging $8 \%$ in young and medium-aged pastures and $3 \%$ in old $(P=0.003)$. Total sown species cover declined with pasture age from $81 \%$ in young pastures to $66 \%$ in old $(P<0.001)$.

Total sown species cover was greater in pastures sown with a GLH mix than a GL mix on sheep and beef farms (78\% vs $68 \%$ ) but similar across pasture type on dairy farms (averaging $75 \%, P=0.002$ ).

Unsown grasses, unsown herbs and total unsown species cover increased with pasture age $(P<0.001$, Table 4$)$. Annual poa (Poa annua L.) was the most prevalent unsown grass (Table 3).

The cover of unsown herbs was greater under pastures sown with a GLH mix than a GL mix on dairy farms (15\% vs $8 \%$ ) but similar across pasture type on sheep and beef farms (averaging 4\%, $P=0.001$ ). Unsown herbs comprised weedy species such as dock (Rumex spp.), pennyroyal (Mentha pulegium L.), thistles (e.g. Californian thistle [Cirsium arvense (L.) Scop.]), buttercup (Ranunculus spp.), yarrow (Achillea millefolium L.) and naturalised plantains (Plantago spp.) with the latter two being most prevalent. Naturalised plantains were more prostrate, with hairier and smaller leaves than commercially sown plantain cultivars. Unsown legumes, of which subterranean clover was the most prevalent, averaged $3 \%$ of ground cover and were similar across farm type, pasture type and pasture age.

Total unsown species cover was greater in pastures sown with a GLH mix than a GL mix on dairy farms (27\% vs $16 \%$ ) but lower in pastures sown with a GLH mix than GL mix on sheep and beef farms $(20 \%$ vs $28 \%, P=0.001)$. The percentage of bare ground decreased with pasture age, from $6 \%$ in young pastures to $3 \%$ in old $(P=0.009$, Table 4$)$. 


\section{Soil seed bank}

There were few main effects of farm type, pasture type or pasture age on seedling emergence from the seed bank (Table 4). Interactions generally demonstrated greater emergence of sown species from the seed bank of pastures sown with the GLH mix than GL mix, and conversely a lower emergence of unsown species in some but not all of the age categories, and on sheep and beef farms but not dairy farms.

The number of sown species that emerged from the seed bank was greater in pastures sown with a GLH mix than GL mix in old pastures (seven and two seedlings $\mathrm{m}^{-2}$, respectively, $P=0.032$ ) but similar across pasture types in young and medium-aged pastures. Emergence of sown species was greater in pastures sown with a GLH mix than a GL mix on sheep and beef farms (16\% vs $4 \%$ of total emergence) but similar across pasture types on dairy farms (averaging $2 \%, P=0.009$ ).

Emergence of unsown grasses from the seed bank was greater in pastures sown with a GLH mix than GL mix in young pastures (53\% vs $23 \%$ of the total number of emerging species) but similar across pasture type in medium-aged (averaging $41 \%$ ) and old pastures (averaging 32\%, $P=0.016$ ).

Emergence of unsown legumes from the seed bank was negligible.

Emergence of unsown herbs from the seed bank was lower in pastures sown with a GLH mix than GL mix on sheep and beef farms (50\% vs $70 \%$ of total emergence) but similar across pasture types on dairy farms (averaging $50 \%, P=0.011$ ). Emergence was also lower in pastures sown with a GLH mix than GL mix in young pastures (35\% vs $74 \%$ ) but similar across medium-aged (averaging 51\%) and old pastures (averaging 61\%, $P=0.006$ ).

The total number of unsown species that emerged from the seed bank was lower in pastures sown with a GLH than GL mix on sheep and beef farms (75 vs 125 seedlings $\mathrm{m}^{-2}$ ) but similar across pasture types on dairy farms (averaging 115 seedlings $\mathrm{m}^{-2}, P=0.033$ ). Similarly, emergence of total unsown species was lower from pastures sown with a GLH mix than a GL mix on sheep and beef farms ( $84 \%$ vs $96 \%$ of the total number of species that emerged) but similar across pasture types on dairy farms (averaging $98 \%, P=0.009$ ).

\section{Endophyte in ryegrasses and fescues}

Infection of tillers with endophyte averaged $69 \pm 6( \pm$ SEM) \%. There were no significant differences in infection levels between farm type, pasture type and pasture age categories $(P>0.05)$.

\section{Invertebrate communities}

Soil-dwelling herbivorous macro-invertebrate communities were generally species-poor (three to 12 species) with composition varying among regions. Species recovered in soil samples comprised predominately the recognised pests grass grub (Costelytra zealandica [White]), black beetle (Heteronychus arator [Fabricius]), white fringed weevil (Naupactus leucoloma Boheman), clover root weevil (Sitona lepidus Gyllenhal) and grey field slug (Deroceras reticulatum [Müller]). Epigeal herbivores were much more diverse (39-61 species) and numerically dominated by Argentine stem weevil (Listronotus bonariensis [Kuschel]) adults, clover root weevil, various aphids-especially cereal aphid (Rhopalosiphum padi L.) -lucerne flea (Sminthurus viridis L.), red-legged earth mite (Halotydeus destructor [Tucker]), plant bugs (Stenotus spp.), grass thrips (Aptinothrips rufus 
[Haliday]), American grass thrips (Anaphothrips obscurus Müller), onion thrips (Thrips tabaci Lindeman), banded thrips (Aeolothrips fasciatus [L.]), wheat sheath miner (Cerodontha australis Malloch), and drosophilid leaf and stem miners (Scaptomyza spp.).

The total abundances of soil-dwelling pest herbivores (averaging $36 \mathrm{~m}^{-2}$ ) and epigeal herbivores (averaging $460 \mathrm{~m}^{-2}$ ) were similar across farm types (data not shown), pasture types and pasture ages $(P>0.05$, Table 5$)$. Of individual pest species, only numbers of the clover root weevil varied significantly among pastures-larval abundance declined with pasture age from $33 \mathrm{~m}^{-2}$ in young pastures to $12 \mathrm{~m}^{-2}$ in old $(P=0.019)$. The total abundance of detritivores increased with pasture age from $1720 \mathrm{~m}^{-2}$ in young pastures to $2930 \mathrm{~m}^{-2}$ in old pastures $(P=0.048)$. The total abundance of predators and parasitoids also increased with pasture age from $310 \mathrm{~m}^{-2}$ in young pastures to $390 \mathrm{~m}^{-2}$ in old pastures $(P<0.003)$ and was greater under pastures sown with herbs than pastures sown without herbs (380 vs $230 \mathrm{~m}^{-2}, P<0.002$, Table 5 ).

Earthworm abundance was higher in medium-aged pastures than in old and young (139 vs an average of $80 \mathrm{~m}^{-2}, P=0.017$ ).

\section{Soil nutrients}

Soil $\mathrm{pH}$ was lower under pastures sown with a grass and legume mix than those sown with herbs $(6.1$ vs $6.3, P=0.013)$. Sulphate sulphur levels were higher from soils sampled on dairy than sheep and beef farms $(20$ vs $10 \mathrm{ppm}, P=0.015)$. There was an interaction between farm type and pasture age in Olsen $\mathrm{P}$ which was greater in soil sampled from under dairy than sheep and beef, but only in old pastures (averaging 45 and $20 \mu \mathrm{g}$ $\mathrm{mL}^{-1}$ respectively, $\left.P<0.001\right)$. Calcium (MAF QT $\left.=13 \pm 1.3\right)$, potassium $(\mathrm{MAF} \mathrm{QT}=10$ \pm 1.9 ), magnesium (MAF QT $=34 \pm 5.4$ ), sodium ( $\mathrm{MAF} \mathrm{QT}=9 \pm 2$ ), organic carbon $(10 \pm 3 \%)$ and organic matter $(18 \pm 4 \%)$ levels were similar across farm type, pasture type and pasture age $(P>0.05, \pm \mathrm{SEM}$, data not shown).

\section{Discussion}

\section{Pasture type (grasses and legumes vs grasses, legumes and herbs) effects}

Evidence of changes in persistence could include improved proportion of ground cover of sown species, and stability in number of sown species. Lesser weed and pest ingress could also be indicative of conditions favouring persistence of sown species. There are several

Table 5. Soil invertebrate abundance on 171 dairy, and sheep and beef pastures, varying in pasture type and pasture age.

\begin{tabular}{|c|c|c|c|c|c|c|c|c|c|}
\hline \multirow[b]{2}{*}{ Variable } & \multicolumn{4}{|c|}{ Pasture type } & \multicolumn{5}{|c|}{ Pasture age } \\
\hline & GLH & $\mathrm{GL}$ & SED & F prob & Young & Medium & Old & SED & F prob \\
\hline \multicolumn{10}{|c|}{ Soil and epigeal invertebrates (per $\mathrm{m}^{2}$ ) } \\
\hline Earthworms & 86 & 112 & 15.3 & ns & 79 & 139 & 80 & 18.3 & 0.017 \\
\hline Clover root weevil larvae & 15 & 30 & 8.1 & ns & 33 & 22 & 12 & 10.1 & 0.019 \\
\hline Total herbivorous pests & 33 & 39 & 10.0 & ns & 44 & 31 & 32 & 12.5 & ns \\
\hline Total herbivores & 450 & 470 & 78 & ns & 440 & 450 & 490 & 97 & ns \\
\hline Total detritivores & 2560 & 2100 & 486 & ns & 1720 & 2340 & 2930 & 619 & 0.048 \\
\hline Total predators and parasitoids & 380 & 230 & 31 & 0.002 & 310 & 320 & 390 & 39 & 0.003 \\
\hline
\end{tabular}


types of evidence that could be used to infer changes in persistence due to the inclusion of forage herbs, namely: (1) pasture type main effects; (2) interactions between pasture type (with vs without forage herbs) and farm type (beef and sheep vs dairy); and (3) interactions between pasture type and pasture age. While no interactions between pasture type and pasture age were evident in ground cover or botanical composition, there were interactions between pasture type and farm type/region.

Ground cover and emergence from the seed bank of sown species was greater, and unsown species ground cover and emergence was lower in pastures sown with forage herbs than without forage herbs, on sheep and beef farms, but not dairy farms. This occurred across the range of pasture ages sampled. These results for sheep and beef farms are consistent with Sanderson et al. (2005), who found that including chicory in a mix containing grasses and legumes resulted in a lower weed \% DM contribution in both wet and dry years for several years after sowing. However, in our study there was no impact of including herbs in the sown mix on sown or unsown species contribution to total DM or on the number of unsown species. This may reflect the small contribution of sown herbs to ground cover and total DM; forage herbs averaged only $6 \%$ of the ground cover and $10 \%$ of total DM. The ground cover and contribution of sown herbs declined with pasture age, suggesting that their contribution declined over time. Their contribution to total DM and ground cover was approximately half that in older pastures (5 or more years since sowing) compared with that in newly sown pastures (1-2 years since sowing).

The low contribution of forage herbs to total DM may be due to a number of management factors during and after sowing. Pastures were predominantly based on perennial ryegrass, which was typically sown in autumn at high rates $\left(>18 \mathrm{~kg} \mathrm{ha}^{-1}\right)$. Perennial ryegrass germinates rapidly and produces vigorous seedlings that may easily outcompete slower establishing species such as chicory (Moot et al. 2000), particularly under high-fertility conditions.

Additionally, grazing management during and after establishment is generally designed to optimise the productivity of one or two of the most dominant species in a sward (such as perennial ryegrass and white clover) and is unlikely to be optimal for forage herbs. Management principles may need to be adapted to target the forage herbs at critical stages to ensure that they can perform well and persist (Pembleton et al. 2015). For example, sowing chicory and plantain as a component of a pasture mix in spring rather than autumn is likely to result in greater forage herb establishment, due to rapid leaf development of these species with increasing spring temperatures (Sanderson \& Elwinger 2000). Avoidance of hard grazing in spring and autumn is also particularly important for chicory regrowth and persistence (Li \& Kemp 2005).

Sowing rates of forage herbs in this study were also low-typically $2-3 \mathrm{~kg} \mathrm{ha}^{-1}$. A higher sowing rate may lead to a greater contribution to the pasture composition (Dodd et al. 2000). Additionally, reducing the sowing rate of grasses, or sowing a binary mixture of forage herbs and legumes, may enhance forage herb establishment and \% DM contribution. In one study, lamb growth rates in autumn were greater on herb-clover swards (comprising plantain, white clover and red clover, or plantain, chicory, white clover and red clover) than on a conventional perennial ryegrass-white clover sward (Somasiri et al. 2015).

Measurements at different times of the year, such as over summer, when chicory grows more actively, may also have led to greater estimates of forage herb contribution to sward 
DM in our study. For example, Dodd et al. (2000) noted a positive correlation between total herbage yield and the percentage contribution of plantain, when assessed in summer-moist hill country in late spring 2 years after sowing. The authors noted that a 10 percentage point increase in plantain content equated to $200 \mathrm{~kg} \mathrm{DM} \mathrm{ha}^{-1}$. The $10 \%$ ground cover contribution (7\% DM contribution) of forage herbs averaged over all pasture ages reported here may therefore make a valuable contribution to feed supply, especially given that forage herbs can extend the growing season and supply feed at times of the year when growth of grasses and legumes is restricted (Pembleton et al. 2015).

There was a greater loss of sown species from pastures sown with forage herbs than without forage herbs, although the total number of species sown was low: 4.3 vs 2.7 in pastures sown with and without forage herbs, respectively. Loss of sown species from the sward is consistent with Tracy and Sanderson (2004) who observed a decline in abundance of sown herbs and legumes from multi-species swards over 4 years. Their field site was fertilised and mown each month from mid-spring to mid-autumn, mimicking an intensively managed rotationally grazed system, as was the case for most pastures sampled in our study. A complex sown mix with diverse morphological traits may not be able to persist in intensively managed high-input pastures due to suboptimal management; the sown composition may shift to a more stable and simpler mixture of species with traits adapted to growth and survival in these systems. This has been demonstrated by Scott (2001) in swards sown with 25 species in South Island high country that was monitored over 19 years. Legumes dominated in the first few years of the study, followed by cocksfoot and Caucasian clover (Trifolium ambiguum M. Bieb) in the second decade, and finally by unsown grasses.

Despite the greater sown species emergence from the seed bank of pastures sown with forage herbs than without forage herbs, sown species comprised only a small proportion of the total emergence (up to $9 \%$ ). The seed bank was dominated by pasture weeds, such as annual poa, and buttercup. Therefore, inclusion of forage herbs in the mix is unlikely to result in agronomic benefits through reseeding of forage herbs and subsequent seedling establishment. The lack of a persistent sown species seed bank is consistent with Bell (1995) who found that weedy species dominated the seed bank of central North Island dairy pastures while perennial ryegrass emergence was negligible. These results most likely reflect the intensive management on many sheep and beef, and especially dairy farms, which had the lowest emergence of sown seedlings from the soil seed bank. Modern management aims to optimise pasture quality through prolonging vegetative growth and reducing the presence of reproductive tillers, whether by intensive grazing or mowing (Macdonald et al. 2011). These practices allow little reseeding and replenishment of the seed bank as would occur if hay were made.

There was some evidence that sowing forage herbs resulted in shifts in the composition of invertebrate communities, with a greater abundance of natural enemies (predators and parasitoids) under pastures sown with herbs. While no published studies investigating the inclusion of forage herbs on invertebrate communities in intensively managed pastures were available for comparison, results are consistent with Knops et al. (1999) who found that there were more predators as the number and types of species in the sward increased up to 16 species. In our study, there was a small but highly significant difference between pasture types in the total number of invertebrate species present in the soil (11 vs 9.3 species in pastures sown with and without forage herbs). The effect of including forage 
herbs on invertebrate community structure is most likely due to differences between pasture types in the food availability for these invertebrates (Curry 1994) rather than the number of species per se. However, with the exception of the natural enemies guild, there were no differences between the pasture types in invertebrate abundance in other invertebrate guilds or in individual species. Our sampling also failed to detect pasture type effects on abundance of herbivorous pest species. Repeated sampling over time would be required to fully determine the impact of including forage herbs in the pasture mix on invertebrate communities, botanical composition and DM production.

\section{Farm type}

The positive response of adding forage herbs to a mix containing grasses and legumes in sheep and beef farms, but neutral or negative response on dairy farms, may be explained by differences between the farm types in management and subsequent impacts on weed ingress and control. Dairy farms are generally more intensively managed than sheep and beef farms, with higher inputs (MacLeod \& Moller 2006) and are subject to more intensive rotational grazing management. The lack of sown species emergence from the seed bank, higher Olsen P levels (depending on the pasture age) and sulphur levels in soil from dairy compared with sheep and beef farms are consistent with greater management intensity. We suggest that high stocking rates, heavier livestock and more intensive grazing regimes typical of dairy farms are more likely to result in pasture damage, plant mortality and creation of canopy gaps in dairy than in sheep and beef pastures, particularly under drought or extremely wet conditions, when pasture pulling (i.e. removal of whole plants during grazing) and pugging can occur (Macdonald et al. 2011). Such practices lead to creation of canopy gaps, which are essential for seedling emergence from the seed bank (Panetta \& Wardle 1992; Bullock 2000). Thus more intensive management, and greater pasture damage and gap creation in dairy than sheep and beef pastures, could be a key reason for the poorer persistence and greater weed ingress on dairy farms.

In contrast to dairy farms, sheep and beef farms are generally less intensively managed with less intensive defoliation and treading. In these pastures it is suggested that the beneficial effects of including forage herbs in the sown mixture are more likely to be detected and less likely to be masked by management factors. Evidence for this is provided by $10 \%$ greater sown species cover and $8 \%$ lower unsown species cover in pastures sown with a GLH mix than a GL mix on the sheep and beef farms but no effect, or a negative effect, of forage herb inclusion on dairy farms.

Additionally, including forage herbs (chicory, plantain or both) in a sown mix reduces the number of herbicide options available for broad-leaved weed control, particularly if wanting to avoid damage to clovers (Manktelow et al. 2005; Young 2012). Farmers may choose not to apply herbicides to enable survival of sown chicory and plantain, with the consequence that broad-leaved weeds are able to proliferate unchecked in pastures with herbs. Anecdotal evidence, in the form of conversations with farmers while collecting farm management data, suggests that this was the case (Tozer et al. 2011) on dairy farms in particular. In contrast, farmers have more broad-leaved weed herbicide options in pastures sown with a grass-clover mix and can therefore more readily control broad-leaved weeds. Therefore, the greater ground cover of weeds in pastures sown with forage herbs than without forage herbs, particularly on dairy farms, may partly be a consequence of management decisions around herbicide application. 


\section{Pasture age effects}

Pasture age had the greatest effect on botanical composition, soil seed bank content and invertebrate abundance, regardless of the pasture type, providing evidence for a decline in persistence as pastures aged. Fewer sown species were detected at the time of sampling than were sown, especially in older pastures. An analysis of the persistence of the sown species in this study inferred that chicory persisted poorly, with a significant decline in the number of pastures in which it was detected, as pastures aged (Tozer et al. 2011). Additionally, red clover was detected in fewer old than young pastures in this study, although the decline was not significant (Tozer et al. 2011). However, there was a significant decline in the proportion of legume from $19 \%$ to $14 \%$ as pastures aged.

White clover was the most frequent legume, other than subterranean clover, in sheep and beef farms in Canterbury. In a survey of 28 sheep and beef properties, Blackwell et al. (2011) found that legume ground cover ranged from 10\%-20\%. This is consistent with our results of sown legume cover ranging from 19\% in young pastures to $14 \%$ in old.

The decline in cover of sown species as pastures aged may reflect that some species were present in the pasture in frequencies too small to detect or that they were lost from the sward. The latter is supported by Sanderson et al. (2005) who found that under dairy cattle grazing, the proportion of red clover and chicory in the sward declined by $80 \%$ after the second year, and the proportion of chicory decreased from $20 \%-25 \%$ in the first year to less than $10 \%$ in the third year. By the end of that study, swards were dominated by sown grasses and the authors concluded that the chicory and legume components would need re-establishing relatively frequently to maintain the production and weed suppression benefits.

Our results are also consistent with Hume et al. (1995) who found that chicory declined from 46 to 15 plants $\mathrm{m}^{-2}$ over 4 years when rotationally grazed by sheep. Consistent with a loss of species from the sward was a strong decline in the proportion of sown species from $88 \%$ in young pastures to $69 \%$ in old. There was a similar decline in ground cover. Decline in pasture biomass within several years of sowing can be high; Thom et al. (1998) reported a decline in the yield of perennial ryegrass of $27 \%$ between the first and second year, and another $6 \%$ between the second and third year, in central North Island dairy pastures. However, our results are in contrast with a recent survey of Waikato-Bay of Plenty, Canterbury and Taranaki dairy pastures, in which there was no significant impact of pasture age on sown species proportion (Tozer et al. 2014). That study was limited to swards sown predominantly with perennial ryegrass and white clover, which may persist better than swards containing species such as red clover and forage herbs such as chicory, as previously discussed. Furthermore, pastures in two of the three regions in that survey (irrigated Canterbury and Taranaki) were unlikely to have been subjected to severe summer droughts, which is in contrast to pastures in most regions in this study.

In contrast to sown species, the number of unsown species increased with pasture age in the sampled pastures, contributing nine of the 12 species that were present in old pastures. This was also consistent with the increase in ground cover and proportion of unsown species as pastures aged, reflecting weed ingress.

There were significant effects of age on invertebrate populations. In the first few years after soil disturbance, such as occurs during pasture renewal, soil pests typically build up. This is followed by an increase in beneficial invertebrates, which leads to a decline in pest 
numbers (Zydenbos et al. 2011). The decline in clover root weevil and trend towards a decline in total soil pests and increase in epigeal herbivores and detritivores as pastures aged may reflect this.

Sulphate sulphur and magnesium levels increased with pasture age, which may reflect repeated fertiliser application and build-up of these nutrients in the soil. Organic carbon and organic matter remained unchanged as pastures aged, inferring sufficient nutrient cycling and nutrient input for these levels to be maintained.

\section{Conclusion}

Including forage herbs increased persistence of sown species and reduced weed ingress, based on sown species ground cover and seed bank emergence data, but only in sheep and beef farms. On dairy farms, the reverse was true. This may be due to management factors associated with a more intensive dairy grazing regime. The intensity of these systems was not conducive to the persistence of forage herbs as indicated by the decline in the number of sown species and the abundance of forage herbs as the pastures aged. There was an increase in total predator and parasitoid numbers under pastures sown with herbs, but this is unlikely to result in agronomic or other measurable benefits in these intensive systems. Management factors, and climate, are likely to be having a greater impact on sown species persistence, weed ingress and invertebrate pest abundance. For forage herbs to have a greater impact on persistence, changes in management, such as reducing grass seeding rates, or sowing binary mixtures of forage herbs and legumes, will be required.

\section{Acknowledgements}

Thanks are due to assistance from Trevor James and Claire Dowsett in seedling identification, and Yuki Fukuda, Mike Trolove and Shona Lamouroux with fieldwork. We would also like to thank the reviewers for their valuable comments and assistance in improving the manuscript.

\section{Disclosure statement}

No potential conflict of interest was reported by the authors.

\section{Funding}

Thanks are due to the Sustainable Farming Fund for provision of funding.

\section{References}

Beef + Lamb New Zealand. 2001. March. Pasture persistence for profits. R\&D Brief 82. Wellington: Beef + Lamb New Zealand; [cited 2016 May 11]. Available from: http://www.beeflambnz.com/ Documents/Farm/Pasture\%20persistence\%20for\%20profits.pdf

Bell CC. 1995. Subtropical seed-bank of a Bay of Plenty dairy farm. Proc New Zeal Grassl Assoc. 57:59-61.

Blackwell G, Lucock D, Moller H, Hill R, Manhire J, Emanuelsson M. 2011. Abundance and diversity of herbaceous weeds in sheep/beef pastures, South Island, New Zealand. New Zeal J Agr Res. 54:53-69.

Bullock JM. 2000. Gaps and seedling colonization. In: Fenner M, editor. Seeds: the ecology of regeneration in plant communities. Wallingford: CABI Publishing; p. 375-395. 
Cornforth IS. 1980. Soil and fertilisers: soil analysis-interpretation. AgLink AST 8. Wellington: New Zealand Ministry of Agriculture and Fisheries.

Cornforth IS, Sinclair AG. 1984. Fertiliser and lime recommendations for pastures and crops in New Zealand. 2nd revised ed. Wellington: New Zealand Ministry of Agriculture and Fisheries.

Curry JP. 1994. Grassland invertebrates: ecology, influence on soil fertility and effects on plant growth. London: Chapman \& Hall.

Dodd MB, Barker DJ, Dymock N, Orr SJ. 2000. Factors influencing the contribution of narrowleaved plantain to North Island hill country pastures. Proc New Zeal Grassl Assoc. 62:179-182.

GenStat. 2010. GenStat for Windows 13.2. Hemel Hempstead: VSN International Ltd.

Goh KM, Bruce GE. 2005. Comparison of biomass production and biological nitrogen fixation of multi-species pastures (mixed herb leys) with perennial ryegrass-white clover pasture with and without irrigation in Canterbury, New Zealand. Agric Ecosyst Environ. 110:230-240.

Hahn H, Huth W, Schoberlein W, Diepenbrock W. 2003. Detection of the endophyte fungi in Festuca spp. by means of tissue print immunoassay. Plant Breed. 122:217-222.

Høgh-Jensen H, Nielsen B, Thamsborg SM. 2006. Productivity and quality, competition and facilitation of chicory in ryegrass/legume-based pastures under various nitrogen supply levels. Euro J Agron. 24:247-256.

Hume DE, Lyons TB, Hay RJM. 1995. Evaluation of 'Grasslands Puna' chicory (Cichorium intybus L.) in various grass mixtures under sheep grazing. New Zeal J Agr Res. 38:317-328.

Jones RM, Hargreaves JNG. 1979. Improvements to the dry-weight-rank method for measuring botanical composition. Grass Forage Sci. 34:181-189.

Kelly S, Smith E. 2011. Pasture renewal in the Waikato and Bay of Plenty regions: an overview of farmer practice, experience and attitudes. Past Persis Grassl Res Pract Ser. 15:21-24.

Knops JMH, Tilman D, Haddad NM, Naeem S, Mitchell CE, Haarstad J, Ritchie ME, Howe KM, Reich PB, Siemann E, Groth J. 1999. Effects of plant species richness on invasion dynamics, disease outbreaks, insect abundances and diversity. Ecol Lett. 2:286-293.

Lavorel S, Grigulis K, McIntyre S, Williams NSG, Garden D, Dorrough J, Berman S, Quétier F, Thébault A, Bonis A. 2008. Assessing functional diversity in the field - Methodology matters! Funct Ecol. 22:134-147.

Lee JM, Hemmingson NR, Minee EMK, Clark CEF. 2012. Chicory and plantain management strategies to increase herbage dry matter yield, nutritive value and plant survival. In: Proceedings of the 5th Australasian Dairy Science Symposium, November 13-15; Melbourne, Australia; p. 393-397.

Leuchtmann A, Bacon CW, Schardl CL, White JF, Tadych M. 2014. Nomenclatural realignment of Neotyphodium species with genus Epichloë. Mycologia. 106:202-215.

Li G, Kemp PD. 2005. Forage chicory (Cichorium intybus L.): a review of its agronomy and animal production. Adv Agron. 88:187-222.

Macdonald KA, Matthew C, Glassey CB, McLean N. 2011. Dairy farm systems to aid persistence. Past Persis Grassl Res Pract Ser. 15:199-210.

MacLeod CJ, Moller H. 2006. Intensification and diversification of New Zealand agriculture since 1960: an evaluation of current indicators of land use change. Agric Ecosyst Environ. 115:201-218.

Manktelow D, Walker SP, Gurnsey S, Park N, Zabkiewicz J, Teulon D, Rahman A. 2005. Trends in pesticide use in New Zealand: 2004. Report to the Ministry for the Environment, Project SMF4193. Auckland: HortResearch.

Moorhead AJE, Piggot GJ. 2009. The performance of pasture mixtures containing 'Ceres Tonic' plantain (Plantago lanceolata) in Northland. Proc New Zeal Grassl Assoc. 71:195-199.

Moot DJ, Scott WR, Roy AM, Nicholls AC. 2000. Base temperature and thermal time requirements for germination and emergence of temperate pasture species. New Zeal J Agr Res. 43:15-25.

Nijland GO. 2000. A variant of the dry-weight rank method for botanical analysis of grassland with dominance-based multipliers. Grass Forage Sci. 55:309-313.

Nobilly F, Bryant RH, McKenzie, BA, Edwards GR. 2013. Productivity of rotationally grazed simple and diverse pasture mixtures under irrigation in Canterbury. Proc New Zeal Grassl Assoc. 75:165-172.

Panetta FD, Wardle DA. 1992. Gap size and regeneration in a New Zealand dairy pasture. Austral Ecol. 17:169-175. 
Patterson HD, Thompson R. 1971. Recovery of inter-block information when block sizes are unequal. Biometrika. 58:545-554.

Pembleton KG, Tozer KN, Edwards GR, Jacobs JL, Turner LR. 2015. Simple versus diverse pastures: opportunities and challenges in dairy systems. Anim Prod Sci. 55:893-901.

Rahman A, James TK, Grbavac N, Mellsop J. 1995. Evaluation of two methods for enumerating the soil weed seedbank. Proc New Zeal Plant Prot Conf. 48:175-180.

Sanderson MA, Elwinger GF. 2000. Seedling development of chicory and plantain. Agron J. 92:69-74.

Sanderson MA, Elwinger GF. 2004. Emergence and seedling structure of temperate grasses at different planting depths. Agron J. 96:685-691.

Sanderson MA, Skinner RH, Barker DJ, Edwards GR, Tracy BF, Wedin DA. 2004a. Plant species diversity and management of temperate forage and grazing land ecosystems. Crop Sci. 44:1132-1144.

Sanderson MA, Soder KJ, Brezezinski N, Muller LD, Skinner RH, Wachendorf M, Taube F, Goslee SC. 2004b. Plant species diversity influences on forage production and performance of dairy cows on pasture. Grassl Sci Euro. 9:1-4.

Sanderson MA, Soder KJ, Muller LD, Klement KD, Skinner RH, Goslee SC. 2005. Forage mixture productivity and botanical composition in pastures grazed by dairy cattle. Agron J. 97:1465-1471.

Scott D. 2001. Sustainability of New Zealand high-country pastures under contrasting development inputs. 7. Environmental gradients, plant species selection, and diversity. New Zeal J Agr Res. 44:59-90.

Soder KJ, Sanderson MA, Stack JL, Muller LD. 2006. Intake and performance of lactating cows grazing diverse forage mixtures. J Dairy Sci. 89:2158-2167.

Somasiri SC, Kenyon PR, Morel PCH, Kemp PD, Morris ST. 2015. Herb-clover mixes increase lamb live weight gain and carcass weight in the autumn period. New Zeal J Agr Res. 58:384-396.

Stewart AV. 1996. Plantain (Plantago lanceolata) - A potential pasture species. Proc New Zeal Grassl Assoc. 58:77-86.

Tait A, Henderson R, Turner R, Zheng Z. 2006. Thin plate smoothing interpolation of daily rainfall for New Zealand using a climatological rainfall surface. Int J Climatol. 26:2097-2115.

Tharmaraj J, Chapman DF, Hill J, Jacobs JL, Cullen BR. 2014. Increasing home-grown forage consumption and profit in non-irrigated dairy systems. 2. Forage harvested. Anim Prod Sci. 54:234-246.

Thom ER, Waugh CD, McCabe RJ. 1998. Growth and persistence of perennial and hybrid ryegrasses when grazed by dairy cows in the central Waikato region of New Zealand. New Zeal J Agr Res. 41:477-486.

Tothill JC, Hargreaves JNG, Jones RM, McDonald CK. 1992. 1. Field sampling. In: Tothill JC, Hargreaves JNG, Jones RM, McDonald CK, editors. BOTANAL: a comprehensive sampling procedure for estimating pasture yield and composition. Revised ed. Brisbane: Division of Tropical Crops and Pastures, CSIRO.

Tozer KN, Cameron CA, Thom ER. 2011. Pasture persistence: farmer observations and field measurements. Past Persis Grassl Res Pract Ser. 15:25-30.

Tozer KN, Chapman DF, Bell NL, Crush JR, King WM, Rennie GM, Wilson DJ, Mapp NR, Rossi L, Aalders LT, Cameron CA. 2014. Botanical survey of perennial ryegrass-based dairy pastures in three regions of New Zealand: implications for ryegrass persistence. New Zeal J Agr Res. 57:1-16.

Tozer KN, Rennie GM, King WM, Mapp NR, Aalders LT, Bell NL, Wilson DJ, Cameron CA, Greenfield RM. 2015. Pasture renewal on Bay of Plenty and Waikato dairy farms: impacts on pasture performance post-establishment. New Zeal J Agr Res. 58:241-258.

Tracy BF, Renne IJ, Gerrish J, Sanderson MA. 2004. Effects of plant diversity on invasion of weed species in experimental pasture communities. Basic Appl Ecol. 5:543-550.

Tracy BF, Sanderson MA. 2004. Productivity and stability relationships in mowed pasture communities of varying species composition. Crop Sci. 44:2180-2186.

Young S. 2012. New Zealand Novachem agrichemical manual. Christchurch: AgriMedia Ltd.

Zydenbos SM, Barratt BIP, Bell NL, Ferguson CM, Gerard PJ, Mcneill MR, Phillips CB, Townsend RJ, Jackson TA. 2011. The impact of insect pests on pasture persistence and their interrelationship with biotic and abiotic factors. Past Persis Grassl Res Pract Ser. 15:109-118. 